\title{
Ali je šolsko nasilje med slovenskimi učenci povezano $\mathrm{z}$ učenjem?
}

\author{
Barbara Japelj Pavešić
}

$\mathrm{N}$

esporno je nasilje nezaželen pojav kjerkoli, še posebej v šolskem okolju. Šola je kraj, kamor se otrok vsak dan vrača in mora v njem preživeti velik del svojega življenja. Ne samo preživeti, ampak opraviti svoje dolžnosti učenja, pridobivanja novih znanj in spretnosti ter socialnih veščin. Bistveno je, da mu okolje pri tem pomaga in nesprejemljivo je vse, kar mu kakorkoli škoduje. Zato so poleg raziskovanja razlogov za nasilje in splošnega prizadevanja za njegovo popolno odpravo iz šolskega prostora zelo pomembne študije povezanosti šolske klime in varnosti z delom in dolžnostmi otroka $\mathrm{v}$ šoli ter z njegovim učnim uspehom. Raziskovalna literatura potrjuje povezanost med večjim nasiljem v okolici šole in na njej z nižjimi dosežki učencev, in sicer po svetu in pri nas, vendar redko izhaja iz vzporednega merjenja izpostavljenosti nasilju in dosežkov na individualni ravni učencev; uporablja neodvisno izmerjene agregirane kazalce nasilja in šolskega uspeha. V naši študiji smo za natančnejše raziskovanje povezanosti zaznave nasilja $\mathrm{z}$ učenjem $\mathrm{v}$ različnih starostih učencev uporabili podatke iz mednarodne študije TIMSS iz leta 20I5, ki je hkrati izmerila učenčevo zaznavo šolskega okolja, tudi z ozirom na svojo izpostavljenost nasilju, in kazalce učenja ter znanja na reprezentativnem vzorcu populacije učencev 4 . in 8 . razreda.

\section{Problem}

Zagotavljanje varnega in spodbudnega šolskega okolja je že nekaj let prioriteta politike in strokovnjakov za razvoj izobraževanja pri nas. Vključuje odpravljanje vsega nasilja iz šolskega prostora za zagotavljanje varnosti in vzpostavljanje pogojev, ki bodo spodbujali učenje. Oboje zahteva 
prepoznavo težav ali ovir in vnos novih idej. Za vzpostavljanje spodbudnega okolja za učenje je pomembno, da šolsko okolje kot takšno prepoznajo učenci. Zato je mogoče učinkoviteje preoblikovati šolski prostor $s$ poznavanjem presoje šolske klime $\mathrm{z}$ učenčeve perspektive. V Sloveniji se soočamo $\mathrm{z}$ nizko motivacijo za učenje, nadpovprečnim znanjem in nizkimi občutki pripadnosti šoli ter s povprečno izpostavljenostjo nasilju, če kazalce opazujemo v mednarodni perspektivi (Mullis, Martin, Foy in Hooper, 2016). V mednarodno izmerjenem kazalcu pripadnosti šoli je vključena učenčeva presoja o občutku svoje varnosti na šoli. Ta je med slovenskimi učenci izjemno nizka (Prusinski, Hastedt in Dohr, 2018). Vzorec povezanosti varnosti na šoli z dosežkom kaže, da četrtošolci, ki se počutijo na šoli manj varne, dosegajo višje dosežke iz matematike kot učenci, ki se počutijo bolj varne. $V$ osmem razredu je obratno. Učenci, ki se počutijo varneje, dosegajo višje znanje kot učenci, ki se počutijo manj varne. $S$ študijo smo imeli namen pojasniti neusklajene vzorce in ugotoviti, kateri posamični dejavniki se statističo značilno povezujejo $\mathrm{z}$ učenjem in znanjem $\mathrm{v}$ posamezni starosti učencev. Raziskovalni vprašanji sta zato, kateri vrsti in koliko nasilnim dogodkom so izpostavljeni učenci po njihovi presoji ter kako se njihova zaznava povezuje $\mathrm{z}$ veseljem do učenja in doseženim znanjem? Iz prepoznavanja povezanosti z znanjem bo mogoče prepoznati prednostna področja intervencije in pozornosti do tistega dogajanja v šolah, ki najbolj ovira učence same.

Že opravljene študije o varnosti na šoli in izpostavljenosti nasilju so potrdile povezavo med varnostjo na šoli in dosežki učencev. Mnoge študije se sicer omejujejo na določene skupine otrok in mladine ali na določena urbana okolja. Izkazalo se je, da ima izpostavljenost nasilju na šoli ob vplivu nasilja iz okolice dodaten nezanemarljiv vpliv na ocene učencev, ki se razlikuje še glede ne demografske karakteristike otrok in spol (Bowen in Bowen, 1999). Več ameriških študij povezanosti nasilja na šoli in v mestni okolici šole s šolskimi dosežki ali znanjem učencev, ki temeljijo na nacionalnem merjenju šolske klime in neodvisno izmerjenih dosežkov na testih znanja vpisanih učencev, potrjujejo povezanost med večjo izpostavljenostjo nasilju in nižjim šolskim uspehom (Milam, Furr-Holden in Leaf, 2010; Henrich, Schwab-Stone, Fanti, Jones in Ruchkin, 2004). Slovenska študija (Košir, Klasinc, Špes, Pirc, Cankar, Horvat, 2019) je potrdila nižji šolski uspeh kot enega od napovednikov učenčevega poročanja o izpostavljenosti nasilju. Šolski dosežek je v študiji kitajskih osnovnošolcev napovedal socialno kompetentnost in medsebojno sprejemanje otrok, vendar pa so socialne kompetence, izpostavljenost agresiji, vodenje šole in medsebojno sprejemanje povratno posamično prispevali $\mathrm{k}$ akademskemu dosežku in potrdili model vzajemnih učinkov med akademskim uspehom 
in socialnimi prilagoditvami (Chen, Rubin in $\mathrm{Li}, 1997)$. $\mathrm{V}$ študiji o izobraževanju imigrantskih otrok je bila izpostavljena povezanost med otrokovim zaznavanem šole kot varnega okolja, incidenco nasilnih dogodkov ter dosežki iz matematike (Chavatzia, Engel in Hastedt, 20I6). Študija iz leta 2003 o slovenskih učencih je potrdila, da je negativna povezanost med doživetim nasiljem $\mathrm{v}$ šoli in agresijo otrok ter dosežki iz matematike in naravoslovja prisotna tako pri nas kot drugje po svetu (Perše, Kozina in Leban, 2008). Učenci v starosti okoli to let so bili predmet primerjalne analize izpostavljenosti nasilju ter dosežkov iz matematike, kjer se je pokazalo, da razlike v dosežkih zaradi obsega doživetega nasilja na šoli obstajajo in se začno pojavljati v najzgodnejšem obdobju šolanja. Hkrati je bila Slovenija po podatkih iz leta 2015 umeščena med države z relativno malo nasilja med četrošolci v šoli in relativno visokimi dosežki (Rutkowski in Rutkowski, 2018). Dejavniki otrokovega doma in šole, kot so večje sodelovanje strašev s šolo, bolj zavzeti učitelji in večje število sošolcev z visokimi akademskimi pričakovanji, so bili prepoznani, da doprinesejo $\mathrm{k}$ varnosti šolskega okolja (Shumov in Lomax, 200I).

Za študij povezave nasilja in učenja potrebujemo zanesljive informacije o pojavih nasilnih dogodkov ter meritve dejavnikov učenja. Otrokom so $\mathrm{v}$ različnih starostnih obdobjih pomembne različne vzpodbude in ovirajo jih različne stvari, poročila otrok o neprijetnih vidikih bivanja v šoli pa se lahko razlikujejo. Nasilni dogodki so kompleksni pojavi, o katerih mlajši otroci težko zanesljivo poročajo, tudi od starejših pa lahko pričakujemo zanesljive podatke le o dogodkih, ki so jih doživeli sami. Kakor redno opozarjajo različni raziskovalci po svetu, analize dejavnikov v izobraževanju ne morejo presoditi o vzroku in posledici, pač pa potrdijo le povezavo med posameznimi spremenljivkami. $V$ živem sistemu izobraževanja namreč ne poznamo vseh posrednih vplivov še drugih neizmerjenih dejavnikov na opazovane ter ne vemo, kako deluje povratna zanka. Motivacija je lahko vzrok in posledica dobrega znanja, zato smemo presojati le o povezanosti med njima, ne pa o smeri povezave. $V$ študiji smo izhajali iz pomembnosti raziskovanja učenčeve zaznave obsega nasilja na šolah in varnosti ter iz že znanih korelacij med nekaterimi dejavniki.

\section{Viri in metode}

Zelo malo raziskav po svetu se ukvarja hkrati z merjenjem nasilja ter učnih rezultatov otrok, da bi lahko raziskovali povezave med obojim, kakor razkriva v svojem prispevku Sardoč (2019), sploh pa nobena na nacionalni ravni. Čeprav to ni njen osnovni namen, pa se je mednarodna raziskava znanja matematike in naravoslovja, TIMSS, pokazala kot dragocen vir informacij, ki omogočajo študij povezanosti zaznave nasilnega vedenja $\mathrm{v}$ 
šoli s šolskimi dejavnostmi všolane populacije. V svojem razvoju merjenja trendov dejavnikov, ki so povezani z znanjem, je raziskava TIMSS v izhodiščih opredelila koncept merjenja varnosti in vzpodbudnosti šolske klime z dvema kazalcema: merjenje občutka otrokove pripadnosti šoli kot oceno varnega šolskega okolja ter neposreden obseg izpostavljenosti nasilju (Mullis in Martin, 2013).

Kazalec pripadnosti šoli meri učenčevo zaznavanje šole kot podpore učenju. Lestvica pripadnosti šoli je izračunana iz poročil učencev o tem, koliko se strinjajo (zelo se strinjam, strinjam se, ne strinjam se, sploh se ne strinjam) $\mathrm{z}$ naslednjimi izjavami: rad sem $\mathrm{v}$ šoli; $\mathrm{v}$ šoli se počutim varno; čutim, da pripadam tej šoli; rad grem $\mathrm{v}$ šolo, da srečam svoje sošolce in sošolke; učitelji in učiteljice na šoli so pošteni do mene; ponosen sem, da obiskujem to šolo; na tej šoli se veliko naučim. Izpostavljenost nasilju meri pogostost nasilnih dogodkov, v katerih je bil učenec žrtev. Meritev je zasnovana tako, da mlajši otroci zmorejo podati zanesljive ocene incidence. Lestvica izpostavljenosti nasilju je za osmošolce izračunana iz poročil učencev, kako pogosto (tedensko, mesečno, letno ali nikoli) doživljajo različno nasilje na šoli: norčevanje ali zmerjanje, izključitev iz igre ali drugih dejavnosti s strani drugih učencev, širjenje laži, krajo svojih predmetov, doživijo udarce ali poškodbe, prisiljeni so početi stvari, ki jih sami ne želijo, o njih se širijo neprijetne informacije, na spletu so objavljene neprijetne stvari o njih ter izražene so jim grožnje. Za četrtošolce seznam dogodkov ne vsebuje postavke o objavi neprijetnih stvari o učencu na spletu, druge postavke pa so enake kot za osmošolce.

Oba kazalca šolske klime zbirata podatke na ravni učencev, zato so vrednosti lestvic določene za vsakega posameznika in omogočajo analize povezanosti z znanjem, ki so ga učenci demonstrirali z reševanjem neodvisnega mednarodnega preizkusa znanja iz matematike in naravoslovja. Vse lestvice so izračunane tako, da večje vrednosti pomenijo bolj pozitivna stališča. Če ima učenec višjo vrednost na lestvici izpostavljenosti nasilju, je doživel manj nasilja in nadlegovanja kot učenec $\mathrm{z}$ nižjo vrednostjo. Višja vrednost na lestvici pripadnosti šoli pomeni občutek večje pripadnosti šoli od vrstnikov z nižjo vrednostjo. Vse lestvice imajo mednarodno povprečje ro točk in standardni odklon 2 točki.

Naklonjenost do učenja je podobno določena lestvica vrednosti, ki temelji na učenčevem strinjanju $\mathrm{z}$ različnimi vidiki učenja določenega predmeta (Mullis, Martin, Foy in Hooper, 2016). Ker naravoslovje v Sloveniji ločeno učimo $v$ treh predmetih, pri biologiji, kemiji in fiziki, so bili učenci vprašani o naklonjenosti do učenja vsakega predmeta posebej in so zanje izračunane ločene lestvice naklonjenosti do kemije, do biologije in do fizike. Stališča do učenja fizike so v Sloveniji podobna kot do 
učenja matematike. $V$ analizi smo se zato omejili na naklonjenost do učenja matematike in do učenja kemije, ki je v povprečju najbolj pozitivna med naklonjenostmi od treh naravoslovnih predmetov (Mullis, Martin, Foy in Hooper, 2016). Dosežki oziroma znanje so rezultati, ki jih je učenec dosegel na preizkusu znanja. Poročani so v kompleksni obliki verjetnostnih vrednosti (ang. Plausible values), izražajo pa točke na mednarodno primerljivih lestvicah (ki pa niso primerljive med različno starimi učenci in med dosežki iz matematike in naravoslovja). Lestvice znanja imajo povprečje 500 točk in standardni odklon Ioo točk.

$\mathrm{Za}$ analizo smo izbrali metodo regresije, ki pokaže linearno odvisnost med kazalci in izmerjenim znanjem ali naklonjenostjo do učenja. Uporabili smo statistično orodje IDB Analyzer, ki je bilo razvito prav za analize podatkov iz mednarodnih primerljivih študij znanja, ki jih izvajata organizaciji IEA in OECD. Pri obravnavi dosežkov in stališč, merjenih z zveznimi lestvicami, ter stališč, merjenih v obliki kategoričnih spremenljivk, IDB Analyzer v kombinaciji s statističnim paketom SPSS omogoča uporabo ustrezne statistične metodologije, ki upošteva specifiko vzorčenja in izračunov dosežkov v tej vrsti raziskav (Martin, Mullis, Hooper, 2016). V regresijske modele smo zajeli izpostavljenost nasilju in občutek pripadnosti šoli kot napovednika dosežka matematike in naravoslovja ter ločeno kot napovednika naklonjenosti do učenja matematike in naravoslovja v 4. razredu oziroma kemije v 8. razredu. Ker so ločeni modeli napovedi naklonjenosti do učenja za fante in dekleta pojasnili različno velike deleže variance, modeli napovedi dosežka pa ne, prikazujemo rezultate prvih ločeno po spolu, rezultate drugih pa za celotni populaciji učencev 4. in 8. razreda.

Lestvici občutka pripadnosti šoli in izpostavljenosti nasilju vsebujeta več postavk, ki imajo različne porazdelitve. Ker nas je zanimalo, kateri neposredni dejavniki so povezani z naklonjenostjo do učenja in dosežki ter ali so različni v dveh starostnih skupinah, smo opravili regresijske analize še s posameznimi postavkami kot napovedniki dosežka in naklonjenosti do učenja, ločeno po spolu in starosti. Izkazalo se je, da so z motivacijo za učenje in dosežki v Sloveniji povezane le nekatere postavke, zato smo v nadaljevanju prikazujemo regresijske napovedi le zanje.

\section{Rezultati}

V prvem koraku smo pregledali povprečne vrednosti vseh opazovanih kazalcev za celotni populaciji učencev 4. in 8. razreda ter ločeno po spolu. Sledili so izračuni regresijskih napovedi, v prvem sklopu napovedi dosežkov ter v drugem sklopu napovedi naklonjenosti do učenja matematike in naravoslovja oziroma kemije. 


\section{Šolska klima in dosežki}

Povprečji na lestvicah izpostavljenosti nasilju na šoli med četrtošolci in osmošolci, ki sta ıo točk, se ne razlikujeta od mednarodnega povprečja (Preglednica I). Med seboj lestvici nista neposredno primerljivi, ker lestvica za osmošolce vsebuje dodatno postavko (objavljanje neprimernih informacij na spletu). Občutek pripadnosti šoli je za obe starosti slovenskih učencev $\mathrm{z} 9$ točkami pod mednarodnim povprečjem ro točk (ki ima standardni odklon 2 točki). Vpogled v mednardne primerjave pokaže, da je za četrtošolce $\mathrm{v}$ spodnji četrtini med drugimi državami, za osmošolce pa najnižji med vsemi drugimi državami in skoraj za I točko (polovico standardnega odklona) nižji od povprečja predzadnje Koreje (Mullis, Martin, Foy, Hooper, 2016). Vsi slovenski povprečni dosežki iz preizkusov znanja iz matematike in naravoslovja $\mathrm{v}$ obeh starostnih skupinah so nad mednarodnim povprečjem 500 točk. Posebej visok je dosežek iz naravoslovja med osmošolci. Naklonjenosti do učenja matematike in naravoslovja sta pod mednarodnim povprečjem in še posebej v 8. razredu izredno nizki tudi v mednarodni primerjavi (Martin, Mullis, Foy in Hooper, 2016; Mullis, Martin, Foy in Hooper, 2016).

Preglednica I: Povprečne vrednosti na lestvicah zaznane izpostavljenosti nasilju, občutka pripadnosti šoli, naklonjenosti do učenja in dosežka; matematika in naravoslovje, 4. in 8. razred.

\begin{tabular}{lcccc}
\multirow{2}{*}{ Kazalci } & \multicolumn{2}{c}{ 4. razred } & \multicolumn{2}{c}{ 8. razred } \\
\cline { 2 - 5 } & Povprečje & St. n. & Povprečje & St. n. \\
Izpostavljenost nasilju & I0 & 0,05 & 10,3 & 0,04 \\
\hline Občutek pripadnosti šoli & 9,5 & 0,06 & 8,5 & 0,04 \\
\hline Naklonjenost do učenja matematike & 9,4 & 0,06 & 8,7 & 0,05 \\
\hline $\begin{array}{l}\text { Naklonjenost do učenja naravoslovja/ } \\
\text { kemije }\end{array}$ & 9,4 & 0,05 & 9,6 & 0,06 \\
\hline Matematični dosežek & 520,8 & 1,88 & 516,5 & 2,08 \\
\hline Naravoslovni dosežek & 543,6 & 2,38 & 551,3 & $2,4 \mathrm{I}$ \\
\hline
\end{tabular}

Regresijske analize so $\mathrm{v}$ 4. razredu pokazale pozitivno povezavo med izpostavljenostjo nasilju na šoli ter dosežkoma iz matematike in naravoslovja, pri predpostavljenem enakem občutku pripadnosti šoli. Učenci, ki poročajo o manj pogostem nasilju nad seboj, imajo višji matematični in višji naravoslovni dosežek. Občutek pripadnosti šoli je negativno povezan $\mathrm{z}$ dosežkoma. Ob enaki zaznani izpostavljenosti nasilju dosegajo učenci, ki imajo močnejši občutek pripadnosti šoli, statistično značilno nižje dosežke (Preglednica 2).

V 8. razredu je situacija drugačna. Iz nizke t-vrednosti (manjša od I.96) je razvidno, da od učenca zaznana izpostavljenost nasilju ni povezana 
z dosežki niti iz matematike niti iz naravoslovja. Občutek pripadnosti šoli pa je pozitivno povezan z dosežki iz matematike in naravoslovja.

Preglednica 2: Regresijska analiza napovedi dosežkov iz matematike in naravoslovja iz učenčevega zaznavanja izpostavljenosti nasilju in občutka pripadnosti šoli.

\begin{tabular}{|c|c|c|c|c|c|c|}
\hline & \multicolumn{3}{|c|}{ 4. razred } & \multicolumn{3}{|c|}{ 8. razred } \\
\hline & $\begin{array}{l}\text { Regresijski } \\
\text { koeficient }\end{array}$ & St. n. & t-vrednost & $\begin{array}{l}\text { Regresijski } \\
\text { koeficient }\end{array}$ & St. $\mathrm{n}$. & t-vrednost \\
\hline \multicolumn{7}{|c|}{ Povezanost z matematičnim dosežkom } \\
\hline $\begin{array}{l}\text { Konstanta } \\
\text { - dosežek }\end{array}$ & 503,85 & 8,58 & $58,7 \mathrm{I}$ & 467,48 & 8,74 & 53,46 \\
\hline $\begin{array}{l}\text { Izpostavljenost } \\
\text { nasilju }\end{array}$ & $3,13^{*}$ & 0,63 & 4,97 & 0,04 & 0,75 & 0,05 \\
\hline \multirow[t]{2}{*}{$\begin{array}{l}\text { Občutek } \\
\text { pripadnosti šoli }\end{array}$} & $-1,50^{*}$ & 0,72 & $-2,09$ & $5,69^{*}$ & $\mathrm{I}, \mathrm{O} 2$ & 5,58 \\
\hline & \multicolumn{2}{|c|}{$\mathrm{R}^{2}=0, \mathrm{OI}(0,00)$} & \multicolumn{4}{|c|}{$\mathrm{R}^{2}=0,02(0,0 \mathrm{I})$} \\
\hline \multicolumn{7}{|c|}{ Povezanost z naravoslovnim dosežkom } \\
\hline $\begin{array}{l}\text { Konstanta } \\
\text { - dosežek }\end{array}$ & 521,99 & 9,07 & 57,53 & 491,05 & 9,76 & 50,33 \\
\hline $\begin{array}{l}\text { Izpostavljenost } \\
\text { nasilju }\end{array}$ & $3,60^{*}$ & 0,72 & 5,02 & 0,17 & 0,79 & $0,2 \mathrm{I}$ \\
\hline \multirow[t]{2}{*}{$\begin{array}{l}\text { Občutek } \\
\text { pripadnosti šoli }\end{array}$} & $-\mathrm{I}, \mathrm{S}^{*}$ & 0,75 & $-2, \mathrm{OI}$ & $6,85^{*}$ & 1,09 & 6,28 \\
\hline & \multicolumn{2}{|c|}{$\mathrm{R}^{2}=0, \mathrm{OI}(0,00)$} & \multicolumn{4}{|c|}{$\mathrm{R}^{2}=0, \mathrm{O} 2(\mathrm{O}, \mathrm{OI})$} \\
\hline
\end{tabular}

*označuje statistično značlne vrednosti.

Vsi štirje regresijski modeli sicer ne pojasnijo več kot $2 \%$ variance vsak.

Šolska klima in naklonjenost do učenja matematike in naravoslovja $\mathrm{V}$ drugem sklopu analiz smo izračunali regesijske napovedi motivacije za učenje matematike in naravoslovja oziroma kemije iz istih dveh napovednikov kot v prvem sklopu: iz učenčevega zaznavanja izpostavljenosti nasilju ter občutka pripadnosti šoli. V četrtem razredu dečki poročajo o večji izpostavljenosti nasilju in nižjem občutku pripadnosti šoli kot deklice, v naklonjenosti do učenja matematike in naravoslovja pa ni statistično značilnih razlik med spoloma. Tudi v osmem razredu dekleta čutijo večjo pripadnost šoli kot fantje, $v$ drugih meritvah pa ni razlik med osmošolci in osmošolkami (Preglednica 3). 
Preglednica 3: Povprečne vrednosti na lestvicah zaznane izpostavljenosti nasilju, občutka pripadnosti šoli in naklonjenosti do učenja po spolu, 4. in 8. razred.

\begin{tabular}{lcccc} 
& \multicolumn{2}{c}{ 4. razred } & \multicolumn{2}{c}{ 8. razred } \\
\cline { 2 - 5 } Dekleta & Povprečje & St. n. & Povprečje & St. n. \\
\hline Izpostavljenost nasilju & & & & \\
\hline Občutek pripadnosti šoli & 10,13 & 0,06 & 10,38 & 0,06 \\
\hline Naklonjenost do učenja matematike & 9,74 & 0,06 & 8,68 & 0,05 \\
\hline Naklonjenost do učenja naravoslovja/ & 9,32 & 0,08 & 8,69 & 0,06 \\
kemije & 9,33 & 0,07 & 9,66 & 0,07 \\
\hline Fantje & & & & \\
\hline Izpostavljenost nasilju & 9,80 & 0,06 & 10,22 & 0,06 \\
\hline Občutek pripadnosti šoli & 9,22 & 0,08 & 8,41 & 0,05 \\
\hline Naklonjenost do učenja matematike & 9,52 & 0,06 & 8,76 & 0,06 \\
\hline Naklonjenost do učenja naravoslovja/ & 9,54 & 0,07 & 9,51 & 0,06 \\
kemije & & & \\
\hline
\end{tabular}

Regresijske analize napovedi naklonjenosti do učenja matematike in naravoslovja za fante pojasnijo večje deleže variance kot za dekleta (Preglednica 4). Model napovedi naklonjenosti do učenja matematike iz občutka pripadnosti šoli in zaznavanja izpostavljenosti nasilju pojasni med dečki v četrtem razredu $25 \%$ variance, med fanti v osmem razredu pa $22 \%$ variance.

$\mathrm{V}$ četrtem razredu je med deklicami naklonjenost do učenja matematike in naravoslovja povezana $\mathrm{z}$ njihovim občutkom pripadnosti šoli, ne pa z zaznavo izpostavljenosti nasilju. $V$ osmem razredu se naklonjnost do učenja matematike in kemije pri dekletih povezuje $\mathrm{z}$ njihovim občutkom pripadnosti šoli. Zaznana izpostavljenost nasilju je z naklonjenostjo do učenja kemije povezana negativno. Povezava z motivacijo za učenje matematike ni statistično značilna.

Pri dečkih v četrtem razredu in fantih v osmem razredu je naklonjenost do učenja matematike in naravoslovja oziroma kemije povezana $\mathrm{z}$ občutkom pripadnosti šoli. $V$ četrtem razredu ni povezana $z$ izpostavljenostjo nasilju, v osmem razredu pa je, presenetljivo, negativno. Učenci, ki poročajo o manjši izpostavljenosti nasilju, kar pomeni večjo vrednost na lestvici, so manj naklonjeni učenju matematike in kemije od učencev, ki poročajo, da so nasilju bolj izpostavljeni. Omeniti je treba, da so vrednosti teh regresijskih koeficientov zelo nizke, kar pomeni zelo majhno spremembo v naklonjenosti do učenja med učenci, ki zaznavajo večjo ali manjšo izpostavljenost nasilju. 
Preglednica 4: Regresijske analize napovedi naklonjenosti do učenja matematike in naravoslovja oz. kemije iz zaznane izpostavljenosti nasilju in občutka pripadnosti šoli po spolu.

\begin{tabular}{|c|c|c|c|c|c|c|}
\hline \multirow[b]{2}{*}{ Napovedniki } & \multicolumn{3}{|c|}{ 4. razred } & \multicolumn{3}{|c|}{ 8. razred } \\
\hline & $\begin{array}{l}\text { Regresijski } \\
\text { koeficient }\end{array}$ & St. n. & t-vrednost & $\begin{array}{l}\text { Regresijski } \\
\text { koeficient }\end{array}$ & St. $\mathrm{n}$. & t-vrednost \\
\hline \multicolumn{7}{|l|}{ Deklice } \\
\hline \multicolumn{7}{|c|}{ Povezanost z naklonjenostjo do učenja matematike } \\
\hline $\begin{array}{l}\text { Konstanta } \\
\text { - naklonjenost }\end{array}$ & 5,23 & $0,3 \mathrm{I}$ & 17,09 & 4,53 & 0,26 & 17,18 \\
\hline Izpostavljenost nasilju & 0,03 & 0,02 & I,36 & $-0,03$ & 0,02 & $-1,08$ \\
\hline $\begin{array}{l}\text { Občutek pripadno- } \\
\text { sti šoli }\end{array}$ & $0,39^{*}$ & 0,02 & 16,15 & $0,5 \mathrm{I}^{*}$ & 0,03 & 17,18 \\
\hline & \multicolumn{3}{|c|}{$\mathrm{R}^{2}=0,17(0,02)$} & \multicolumn{2}{|c|}{$\mathrm{R}^{2}=0,17(0,02)$} & \\
\hline \multicolumn{7}{|c|}{ Povezanost z naklonjenostjo do učenja učenja naravoslovja/kemije } \\
\hline $\begin{array}{l}\text { Konstanta } \\
\text { - naklonjenost }\end{array}$ & $5,8 \mathrm{I}$ & 0,35 & 16,75 & 6,90 & $0,4 \mathrm{I}$ & 16,66 \\
\hline Izpostavljenost nasilju & 0,02 & 0,03 & 0,63 & $-\mathrm{O}, \mathrm{IO}^{*}$ & 0,03 & $-3,42$ \\
\hline $\begin{array}{l}\text { Občutek pripadno- } \\
\text { sti šoli }\end{array}$ & $0,34^{*}$ & 0,03 & $\mathrm{I} 2, \mathrm{IO}$ & $0,43^{*}$ & 0,03 & 12,63 \\
\hline & \multicolumn{3}{|c|}{$\mathrm{R}^{2}=\mathrm{O}, \mathrm{II}(\mathrm{O}, \mathrm{O} 2)$} & \multicolumn{2}{|c|}{$\mathrm{R}^{2}=0, \mathrm{IO}(0,02)$} & \\
\hline \multicolumn{7}{|l|}{ Dečki } \\
\hline \multicolumn{7}{|c|}{ Povezanost z naklonjenostjo do učenja matematike } \\
\hline $\begin{array}{l}\text { Konstanta } \\
\text { - naklonjenost }\end{array}$ & 4,90 & 0,34 & 14,26 & 5,01 & 0,26 & 19,13 \\
\hline Izpostavljenost nasilju & 0,00 & 0,02 & $-0,14$ & $-0,07^{*}$ & 0,02 & $-3,08$ \\
\hline $\begin{array}{l}\text { Občutek pripadno- } \\
\text { sti šoli }\end{array}$ & $0,50^{*}$ & 0,03 & 19,43 & $0,53^{*}$ & 0,02 & 21,62 \\
\hline & \multicolumn{3}{|c|}{$\mathrm{R}^{2}=0,25(0,02)$} & \multicolumn{2}{|c|}{$\mathrm{R}^{2}=0,22(0,02)$} & \\
\hline \multicolumn{7}{|c|}{ Povezanost z naklonjenostjo do učenja naravoslovja/kemije } \\
\hline $\begin{array}{l}\text { Konstanta } \\
\text { - naklonjenost }\end{array}$ & 6,06 & 0,32 & 18,91 & 6,76 & $0,3 \mathrm{I}$ & 22,00 \\
\hline Izpostavljenost nasilju & $-0,02$ & 0,03 & $-0,60$ & $-0,05^{*}$ & 0,02 & $-2,52$ \\
\hline $\begin{array}{l}\text { Občutek pripadno- } \\
\text { sti šoli }\end{array}$ & $0,39^{*}$ & 0,03 & 15,56 & $0,39^{*}$ & ০,०4 & 11,07 \\
\hline & \multicolumn{3}{|c|}{$\mathrm{R}^{2}=0, \mathrm{I}_{4}(0, \mathrm{O} 2)$} & \multicolumn{2}{|c|}{$\mathrm{R}^{2}=\mathrm{O}, \mathrm{II}(0, \mathrm{O} 2)$} & \\
\hline
\end{tabular}

* označuje statistično značilne vrednosti.

\section{Posamezni vidiki pripadnosti šoli in nasilja na šoli}

Med slovenskimi učenci četrtega razreda smo s preliminarno regresijsko analizo napovedi naklonjenosti do učenja matematike $s$ šestimi postavkami lestvice merjenja občutka pripadnosti šoli kot napovedniki ugotovili, da so z naklonjenostjo do učenja matematike značilno povezane štiri 
postavke (rad sem v šoli; v šoli se počutim varno; ponosen sem, da obiskujem to šolo, in na tej šoli se veliko naučim), ki smo jih nato vključili v končni napovedni model. Večina učencev je soglašala ali zelo soglašala s štirimi izjavami, med njimi najbolj z izjavo, da se v šoli veliko naučijo in najmanj, da so radi v šoli, še posebej dečki (Preglednica s).

Preglednica 5: Odstotki četrtošolcev po soglasju s postavkami pripadnosti šoli.

\begin{tabular}{|c|c|c|c|c|c|c|c|c|}
\hline Izjave & Zelo se & trinjam & Strin & m se & Ne stri & jam se & $\begin{array}{r}\text { Splc } \\
\text { ne str }\end{array}$ & $\begin{array}{l}\text { se } \\
\text { njam. }\end{array}$ \\
\hline$\%$ odgovorov & Deklice & Dečki & Deklice & Dečki & Deklice & Dečki & Deklice & Dečki \\
\hline Rad sem v šoli. & 40 & 30 & 46 & 40 & 9 & I4 & 5 & 16 \\
\hline $\begin{array}{l}\text { V šoli se poču- } \\
\text { tim varno. }\end{array}$ & 55 & $5 \mathrm{I}$ & 38 & 35 & 5 & 8 & 2 & 6 \\
\hline $\begin{array}{l}\text { Ponosen sem, } \\
\text { da obiskujem } \\
\text { to šolo. }\end{array}$ & 62 & 54 & $3 \mathrm{I}$ & $3 \mathrm{I}$ & 5 & 8 & 2 & 7 \\
\hline $\begin{array}{l}\text { Na tej šoli se ve- } \\
\text { liko naučim. }\end{array}$ & 77 & 74 & 22 & 22 & I & 2 & ○ & 2 \\
\hline
\end{tabular}

Regresijska analiza je učence, ki so izbrali vsako odgovorno kategorijo, primerjala z izhodiščno, to je $\mathrm{z}$ učenci, ki so z izjavami zelo soglašali (Preglednica 6). Regresijski koeficienti pomenijo spremembo v naklonjenosti do učenja matematike glede na izhodiščno skupino. Očitna je razlika med spoloma, saj so vse posamezne postavke statistično značilni napovedniki za dečke, medtem ko je pri deklicah v celoti značilen napovednik le izjava $\gg$ rada sem $v$ šoli $\ll$.

Med postavkami kot najmočnejši napovednik izstopa izjava »rad sem v šoli«. Iz t-vrednosti ugotovimo, da je naklonjenost do učenja matematike med učenci, ki so zelo radi v šoli, statistično značilno večja kot med vsemi, ki so v šoli manj radi. Pri deklicah soglasje z izjavo »rada sem $\mathrm{v}$ šoli« napoveduje večje razlike v naklonjenosti do učenja kot med dečki.

Učenke, ki zelo soglašajo, da se v šoli počutijo varno, so bolj naklonjene učenju matematike kot učenke, ki zgolj soglašajo $s$ to izjavo. Tistih, ki ne soglašajo, da so v šoli varne, je zelo malo in razlike niso značilne. Med dečki manjše soglasje z izjavo, da se v šoli počutijo varno, napoveduje statistično značilen padec naklonjenosti do učenja od skupine dečkov, ki so zelo radi v šoli, vendar so napovedani padci manjši kot pri deklicah.

Soglasje $\mathrm{z}$ izjavo $\gg$ ponosen sem, da obiskujem to šolo $\ll$ je povezano z naklonjenostjo do učenja matematike med dečki, ne pa med 98 
deklicami. Manjše soglasje z izjavo napoveduje manjšo naklonjenost do učenja matematike. Podobno je soglasje z izjavo »na tej šoli se veliko naučim « povezano z naklonjenostjo do učenja med dečki. Med deklicami napoveduje manjšo naklonjenost do učenja le tistim, ki se z izjavo ne strinjajo.

Rezultati kažejo, da napovedni model naklonjenosti do učenja pojasni $25 \%$ variance med deklicami in $29 \%$ med dečki. Stališča dečkov so torej drugače povezana z motivacijo za učenje.

Preglednica 6: Regresijska analiza napovedi postavk občutka pripadnosti šoli na naklonjenost do učenja matematike v 4. razredu.

\begin{tabular}{|c|c|c|c|c|c|c|}
\hline \multirow[b]{2}{*}{ Napovedniki } & \multicolumn{3}{|c|}{ Deklice } & \multicolumn{3}{|c|}{ Dečki } \\
\hline & $\begin{array}{l}\text { Regresijski } \\
\text { koeficient }\end{array}$ & St. n. & t-vrednost & $\begin{array}{l}\text { Regresijski } \\
\text { koeficient }\end{array}$ & St. n. & t-vrednost \\
\hline Konstanta-naklonjenost & 10,33 & 0,07 & 140,64 & 10,83 & 0,07 & 162,94 \\
\hline \multicolumn{7}{|l|}{ Radsemvšoli. } \\
\hline Strinjam se. & $-\mathrm{I}, \mathrm{II} \mathrm{I}^{*}$ & $0, \mathrm{I}$ & $-10,86$ & $-0,83^{*}$ & $0, \mathrm{I}$ & $-8,59$ \\
\hline Ne strinjam se. & $-2,0^{*}$ & 0,14 & $-13,8 \mathrm{I}$ & $-\mathrm{I}, \mathrm{O} 4^{*}$ & 0,15 & $-7,06$ \\
\hline Sploh se ne strinjam. & $-2,42^{*}$ & 0,21 & $-11,36$ & $-\mathrm{I}, 7 \mathrm{I}^{*}$ & 0,19 & $-9,16$ \\
\hline \multicolumn{7}{|l|}{ V šoli se počutim varno. } \\
\hline Strinjam se. & $-0,23^{*}$ & 0,08 & $-2,82$ & $-0,21^{*}$ & 0,09 & $-2,39$ \\
\hline Ne strinjam se. & $-0,07$ & 0,18 & $-0,4 \mathrm{I}$ & $-0,55^{*}$ & 0,18 & $-3,09$ \\
\hline Sploh se ne strinjam. & $0,3 \mathrm{I}$ & 0,29 & 1,05 & $-0,6^{*}$ & 0,21 & $-2,9 \mathrm{I}$ \\
\hline \multicolumn{7}{|c|}{ Ponosen sem, da obiskujem to šolo. } \\
\hline Strinjam se. & $-0,19$ & $0, \mathrm{I}$ & $-1,85$ & $-0,38^{*}$ & 0,12 & $-3,34$ \\
\hline Ne strinjam se. & $-0,13$ & $\mathrm{O}, \mathrm{I} 8$ & $-0,72$ & $-0,86^{*}$ & 0,18 & $-4,78$ \\
\hline Sploh se ne strinjam. & $-0,5$ & 0,32 & $-\mathrm{I}, 54$ & $-0,9^{*}$ & 0,22 & $-4,00$ \\
\hline \multicolumn{7}{|l|}{ Na tej šoli se veliko naučim. } \\
\hline Strinjam se. & $-0,09$ & 0,12 & $-0,78$ & $-0,46^{*}$ & $\mathrm{O}, \mathrm{I}$ & $-4,60$ \\
\hline Ne strinjam se. & $-0,89^{*}$ & 0,43 & $-2,07$ & $-\mathrm{I}, \mathrm{O} 8^{*}$ & 0,23 & $-4,65$ \\
\hline \multirow[t]{2}{*}{ Sploh se ne strinjam. } & $-2,08^{*}$ & $0,8 \mathrm{I}$ & $-2,57$ & $-1,29^{*}$ & 0,4 & $-3,24$ \\
\hline & \multicolumn{3}{|c|}{$\mathrm{R}^{2}=0,25(0,02)$} & \multicolumn{3}{|c|}{$\mathrm{R}^{2}=0,29(0,02)$} \\
\hline
\end{tabular}

$\mathrm{V}$ osmem razredu je preliminarna regresijska analiza pokazala, da so $\mathrm{z}$ naklonjenostjo do učenja matematike povezana soglasja z izjavami: rad sem v šoli; rad grem v šolo, da srečam svoje sošolce in sošolke; učitelji in učiteljice na šoli so pošteni do mene in na tej šoli se veliko naučim (Preglednica 7). 
Preglednica 7: Odstotki osmošolcev po soglasju s postavkami pripadnosti šoli.

\begin{tabular}{|c|c|c|c|c|c|c|c|c|}
\hline \multirow{2}{*}{$\begin{array}{c}\text { Izjave } \\
\% \\
\text { odgovorov }\end{array}$} & \multicolumn{2}{|c|}{ Zelo se strinjam } & \multicolumn{2}{|c|}{ Strinjam se } & \multicolumn{2}{|c|}{ Ne strinjam se } & \multicolumn{2}{|c|}{$\begin{array}{c}\text { Sploh se ne } \\
\text { strinjam }\end{array}$} \\
\hline & Dekleta & Fantje & Dekleta & Fantje & Dekleta & Fantje & Dekleta & Fantje \\
\hline $\begin{array}{l}\text { Rad sem } \\
\text { v šoli. }\end{array}$ & 7 & 6 & 52 & $4 \mathrm{I}$ & 29 & 30 & I2 & 23 \\
\hline $\begin{array}{l}\text { Rad grem } \\
\text { v šolo, da } \\
\text { srečam svo- } \\
\text { je sošolce in } \\
\text { sošolke. }\end{array}$ & 57 & 50 & 35 & 42 & 5 & 5 & 3 & 3 \\
\hline $\begin{array}{l}\text { Učitelji in } \\
\text { učiteljice na } \\
\text { šoli so pošte- } \\
\text { ni do mene. }\end{array}$ & I5 & I5 & 59 & 49 & 20 & 22 & 6 & I4 \\
\hline $\begin{array}{l}\text { Ponosen } \\
\text { sem, da obi- } \\
\text { skujem to } \\
\text { šolo. }\end{array}$ & $2 \mathrm{I}$ & 30 & 53 & 48 & 19 & 8 & 7 & 14 \\
\hline $\begin{array}{l}\text { Na tej šoli } \\
\text { se veliko } \\
\text { naučim. }\end{array}$ & $2 \mathrm{I}$ & $2 I$ & 66 & 60 & IO & I2 & 3 & 7 \\
\hline
\end{tabular}

Regresijska analiza je za učence 8 . razreda pokazala statistično značilno povezavo med soglasjem s tremi izjavami in naklonjenostjo do učenja pri obeh spolih. Soglasje z izjavo »rad grem v šolo, da srečam svoje sošolce in sošolke « je povezano z naklonjenostjo do učenja le med dekleti. Bolj, ko so učenci radi v šoli, ocenjujejo, da so učitelji in učiteljice na šoli do njih pošteni, in menijo, da se na šoli veliko naučijo, bolj so naklonjeni učenju matematike. Dekleta, ki gredo raje v šolo, da tam srečajo prijatelje, so bolj naklonjena učenju matematike kot dekleta, ki gredo v šolo zaradi prijateljev manj rada.

Učenci, ki sploh niso radi v šoli, to je skoraj četrtina fantov, na lestvici naklonjenosti do učenja matematike imajo po napovedi več kot dve točki manj od tistih, ki so zelo radi v šoli, toliko kot slovensko povprečje te lestvice zaostaja za mednarodnim. Pri drugih postavkah so razlike manjše. Model je pojasnil $26 \%$ variance med dekleti in $27 \%$ variance med fanti (Preglednica 8). 
Preglednica 8: Regresijska analiza postavk občutka pripadnosti šoli na naklonjenost do učenja matematike v 8 . razredu.

\begin{tabular}{|c|c|c|c|c|c|c|}
\hline \multirow[b]{2}{*}{ Napovedniki } & \multicolumn{3}{|c|}{ Dekleta } & \multicolumn{3}{|c|}{ Fantje } \\
\hline & $\begin{array}{l}\text { Regresijski } \\
\text { koeficient }\end{array}$ & St. n. & t-vrednost & $\begin{array}{l}\text { Regresijski } \\
\text { koeficient }\end{array}$ & St. n. & t-vrednost \\
\hline $\begin{array}{l}\text { Konstanta- } \\
\text { naklonjenost do uče- } \\
\text { nja matematike }\end{array}$ & 10,28 & 0,18 & 56,24 & 10,70 & 0,19 & 57,75 \\
\hline \multicolumn{7}{|l|}{ Rad sem všoli. } \\
\hline Strinjam se. & $-0,64^{*}$ & 0,16 & $-3,86$ & $-0,77^{*}$ & 0,19 & $-4,07$ \\
\hline Ne strinjam se. & $-1.42^{*}$ & 0,18 & $-7,93$ & $-1,5^{*}$ & 0,2 & $-7,44$ \\
\hline Sploh se ne strinjam. & $-2,35^{*}$ & 0,23 & $-10,44$ & $-2, I^{*}$ & $0,2 \mathrm{I}$ & $-9,84$ \\
\hline \multicolumn{7}{|c|}{ Rad grem v šolo, da srečam svoje sošolce in sošolke. } \\
\hline Strinjam se. & $0,24^{*}$ & 0,08 & 3,06 & $0,19^{*}$ & 0,08 & 2,29 \\
\hline Ne strinjam se. & $0,44^{*}$ & 0,14 & 3,07 & $-0,13$ & 0,17 & $-0,77$ \\
\hline Sploh se ne strinjam. & $-0,43$ & 0,28 & $-\mathrm{I}, 5$ & $-0,15$ & $0,2 \mathrm{I}$ & $-0,7$ \\
\hline \multicolumn{7}{|c|}{ Učitelji in učiteljice na šoli so pošteni do mene. } \\
\hline Strinjam se. & $-0,29^{*}$ & 0,13 & $-2,12$ & $-0,28^{*}$ & 0,12 & $-2,2 \mathrm{I}$ \\
\hline Ne strinjam se. & $-0,62^{*}$ & 0,15 & $-4,2$ & $-0,56^{*}$ & 0,12 & $-4,47$ \\
\hline Sploh se ne strinjam. & $-0,77^{*}$ & 0,27 & $-2,85$ & $-0,7^{*}$ & 0,17 & $-4,14$ \\
\hline \multicolumn{7}{|c|}{ Na tej šoli se veliko naučim. } \\
\hline Strinjam se. & $-0,3^{*}$ & $\mathrm{O}, \mathrm{II}$ & $-2,72$ & $-0,4^{*}$ & $0, \mathrm{II}$ & $-3,65$ \\
\hline Ne strinjam se. & $-0,74^{*}$ & $\mathrm{O}, 18$ & $-4,18$ & $-0,62^{*}$ & 0,17 & $-3,68$ \\
\hline \multirow[t]{2}{*}{ Sploh se ne strinjam. } & $-\mathrm{I}, \mathrm{O} 4^{*}$ & 0,28 & $-3,76$ & $-I, 26^{*}$ & 0,2 & $-6,19$ \\
\hline & \multicolumn{3}{|c|}{$\mathrm{R}^{2}=0,26(0,02)$} & \multicolumn{3}{|c|}{$\mathrm{R}^{2}=0,27(0,02)$} \\
\hline
\end{tabular}

Povezanost občutka pripadnosti šoli z dosežki je zelo majhna in $\mathrm{v}$ večini posameznih postavk ni bila značilna, še posebej med dekleti. Regresijski modeli so pojasnili le do 2 \% variance med dosežki. Večjo povezanost so pokazale analize povezanosti izpostavljenosti nasilju z dosežki in naklonjenostjo do učenja.

$\mathrm{Z}$ izpostavljenostjo nasilju so se dosežki v 4. razredu izkazali za statistično značilno povezane s postavkami: izključili so me iz igre ali drugih dejavnosti; o meni so širili laži; nekaj so mi ukradli; širili so neprijetne informacije o meni in grozili so mi. Velika večina učencev je za večino primerov nasilja označila, da jih ne doživi nikoli ali pa le nekajkrat na leto (Preglednica 9). Zato smo v regresijskem modelu opazovali razlike v napovedani vrednosti dosežkov in naklonjenosti do učenja od skupine, ki je označila, da nasilja na šoli ne doživi nikoli. 
Preglednica 9: Odstotki četrtošolcev po svojem zaznavanju izpostavljenosti nasilju.

\begin{tabular}{|c|c|c|c|c|c|c|c|c|}
\hline \multirow{2}{*}{$\frac{\text { Izjave }}{\text { \% odgovorov }}$} & \multicolumn{2}{|c|}{ Tedensko } & \multicolumn{2}{|c|}{ Mesečno } & \multicolumn{2}{|c|}{ Letno } & \multicolumn{2}{|c|}{ Nikoli } \\
\hline & Deklice & Dečki & Deklice & Dečki & Deklice & Dečki & Deklice & Dečki \\
\hline $\begin{array}{l}\text { Izključili so me } \\
\text { iz igre ali dru- } \\
\text { gih dejavnosti. }\end{array}$ & IO & I2 & 10 & I2 & 23 & 20 & 57 & 56 \\
\hline $\begin{array}{l}\text { O meni so širi- } \\
\text { li laži. }\end{array}$ & IO & I4 & 9 & 9 & 20 & I8 & 6I & 59 \\
\hline $\begin{array}{l}\text { Nekaj so mi } \\
\text { ukradli. }\end{array}$ & 5 & 9 & 5 & 6 & 16 & $2 \mathrm{I}$ & 74 & 64 \\
\hline $\begin{array}{l}\text { Širili so nepri- } \\
\text { jetne informa- } \\
\text { cije o meni }\end{array}$ & 5 & 10 & 7 & 7 & I9 & I 4 & 69 & 69 \\
\hline Grozili so mi. & 5 & 8 & 3 & 5 & II & I4 & $8 \mathrm{I}$ & 73 \\
\hline
\end{tabular}

$\mathrm{Z}$ naravoslovnim dosežkom $\mathrm{v}$ 4. razredu je zaznavanje nasilja $\mathrm{v}$ šoli različno povezano med deklicami in dečki. Pri deklicah izključenost iz igre ali sodelovanja ni povezana z dosežki, pri dečkih pa je. Dečki, ki so jih drugi nekajkrat v letu izključili z družbe, dosegajo kar 25 točk manj od dečkov, ki niso nikoli izključeni. Dečki, ki poročajo, da so izključeni večkrat na mesec, pa se po dosežku ne razlikujejo značilno od tistih, ki niso nikoli izključeni iz igre (Preglednica Io). Širjenje laži se v tem modelu ni izkazalo za povezano z dosežki. $Z$ dosežki pa so povezane kraje ali tatvine. Deklice, ki so navedle, da jim kdo kaj ukrade vsak teden, in dečki, ki jim kradejo vsak teden ali vsak mesec, imajo precej nižje dosežke kot učenci, ki kraje ne doživljajo. Dečki, ki so navedli, da so okradeni vsak teden, so dosegli kar 40 točk manj kot tisti, ki jim nikoli nič ne zmanjka, kar je skoraj polovica standardne napake dosežka (ki je ıoo točk). Pri deklicah je zaostanek manjši, vendar tudi zelo visok in med vsemi postavkami najvišji. Mnogo manj na znanje vpliva širjenje neprijetnih informacij. To prizadene znanje deklic, ki se s širjenjem neprijetnih informacij srečajo nekajkrat na leto, vendar pa tudi dečke, ki to doživijo vsak teden. Tedensko doživljanje groženj, čeprav jih zaznava vsak teden malo otrok, tudi napoveduje 24 oziroma 28 točk nižje dosežke pri dečkih oziroma deklicah od tistih, ki groženj niso deležni. 
Preglednica ıo: Regresijska analiza napovedi naravoslovnih dosežkov s postavkami zaznane izpostavljenosti nasilju v 4. razredu.

\begin{tabular}{lcccccc} 
& \multicolumn{5}{c}{ Deklice } & \multicolumn{3}{c}{ Dečki } \\
\cline { 2 - 7 } Napovedniki & $\begin{array}{l}\text { Regresijski } \\
\text { koeficient }\end{array}$ & St. n. & t-vrednost & $\begin{array}{c}\text { Regresijski } \\
\text { koeficient }\end{array}$ & St. n. & t-vrednost \\
$\begin{array}{l}\text { Konstanta- } \\
\text { naravoslovni } \\
\text { dosežek }\end{array}$ & 541,86 & 3,47 & 156,00 & 548,43 & 3,69 & 148,60 \\
\hline $\begin{array}{l}\text { Izključiliso me iz igre alidrugih dejavnosti. } \\
\text { Tedensko }\end{array}$ & 3,97 & 8,53 & 0,46 & 1,43 & 7,04 & 0,20 \\
\hline Mesečno & $-0,59$ & 6,52 & $-0,09$ & 10,44 & 5,83 & 1,79 \\
\hline Letno & 8,16 & 4,22 & 1,93 & 24,95 & 6,10 & 4,09 \\
\hline
\end{tabular}

O meni so širili laži.

\begin{tabular}{|c|c|c|c|c|c|c|}
\hline Tedensko & $-\mathrm{IO}, 78$ & 9,75 & $-\mathrm{I}, \mathrm{II}$ & $-\mathrm{II}, \mathrm{I} 6$ & 7,73 & $-\mathrm{I}, 44$ \\
\hline Mesečno & $-0,64$ & 7,36 & $-0,09$ & $-7,22$ & 7,38 & $-0,98$ \\
\hline Letno & 8,15 & 5,38 & 1,52 & $6,4 \mathrm{I}$ & 5,04 & 1,27 \\
\hline \multicolumn{7}{|c|}{ Nekaj so mi ukradli. } \\
\hline Tedensko & $-28,06$ & II,I9 & $-2,5 \mathrm{I}$ & $-40,73$ & 7,63 & $-5,34$ \\
\hline Mesečno & $-12,62$ & 7,41 & $-1,70$ & $-24,00$ & 7,98 & $-3,01$ \\
\hline Letno & $-3,17$ & 4,94 & $-0,64$ & $-6,84$ & 5,56 & $-1,23$ \\
\hline \multicolumn{7}{|c|}{ Širili so neprijetne informacije o meni. } \\
\hline Tedensko & $-7,96$ & 9,84 & $-0,8 \mathrm{I}$ & 20,13 & 8,90 & 2,26 \\
\hline Mesečno & 0,07 & 6,84 & O,OI & 8,67 & 8,10 & 1,07 \\
\hline Letno & 11,05 & 4,77 & 2,32 & 0,10 & 5,71 & 0,02 \\
\hline \multicolumn{7}{|c|}{ Grozili so mi. } \\
\hline Tedensko & $-27,69$ & 11,26 & $-2,46$ & $-23,75$ & 10,25 & $-2,32$ \\
\hline Mesečno & $-20,45$ & 10,79 & $-1,90$ & $-8,42$ & 9,05 & $-0,93$ \\
\hline \multirow[t]{2}{*}{ Letno } & $-10,49$ & 5,78 & $-\mathrm{I}, 82$ & 3,80 & 5,11 & 0,74 \\
\hline & \multicolumn{3}{|c|}{$\mathrm{R}^{2}=0,06(\mathrm{O}, \mathrm{OI})$} & \multicolumn{3}{|c|}{$\mathrm{R}^{2}=0,07(\mathrm{O}, \mathrm{OI})$} \\
\hline
\end{tabular}

$\mathrm{V}$ osmem razredu so z dosežki iz matematike povezane postavke o izključenosti iz igre ali sodelovanja, širjenju laži in siljenju v početje neželenih stvari (Preglednica Iı). Zanimivo je, da imajo dekleta, ki so poročala, da so nekajkrat na leto izključena iz družbe ali dejavnosti, napovedan za Io točk višji matematični dosežek od deklet, ki niso nikoli izključena iz družbe. Pri fantih izključevanje iz družbe ni povezano z dosežki iz matematike, prav tako tudi ne širjenje laži. Med dekleti ima širjenje laži precejšen vpliv na dosežke, saj tedensko ali mesečno redno spopadanje z lažmi 
napoveduje znižanje dosežka za 20 točk oziroma i 8 točk. Najbolj izrazito znižanje dosežka pri fantih napovedujejo zaznani dogodki, v katerih je učenec prisiljen, da počne nekaj, česar ne želi. Med dekleti je takih primerov zelo malo, zato tudi analiza ni potrdila značilnih razlik v dosežkih. Tistim učencem, ki jih drugi prisilijo, da vsak teden počnejo nekaj, česar ne želijo (jih je $2 \%$ ), model napove za 4I točk nižji matematični dosežek, za 3I točk nižjega, če se to učencu dogaja mesečno (takih učencev je $3 \%$ ) in za I8 točk nižji dosežek iz matematike, če je učenec prisiljen v sodelovanje proti svoji volji nekajkrat na leto (takih učencev je $8 \%$ ).

Preglednica II: Regresijska analiza napovedi matematičnih dosežkov iz zaznane izpostavljenosti nasilju v 8. razredu.

\begin{tabular}{|c|c|c|c|c|c|c|}
\hline & \multicolumn{3}{|c|}{ Dekleta } & \multicolumn{3}{|c|}{ Fantje } \\
\hline & $\begin{array}{l}\text { Regresijski } \\
\text { koeficient }\end{array}$ & St. n. & t-vrednost & $\begin{array}{c}\text { Regresijski } \\
\text { koeficient }\end{array}$ & St. n. & t-vrednost \\
\hline $\begin{array}{l}\text { Konstanta- } \\
\text { matematični } \\
\text { dosežek }\end{array}$ & 516.07 & 3.04 & 169,76 & 517,90 & 3,10 & 166,92 \\
\hline \multicolumn{7}{|c|}{ Izključili so me iz igre ali drugih dejavnosti. } \\
\hline Tedensko & 0,09 & $\mathrm{I} 2.4 \mathrm{I}$ & O,OI & $-6,23$ & 11,23 & $-0,55$ \\
\hline Mesečno & 13,55 & 10,65 & 1,27 & $-14,27$ & 7,55 & $-1,89$ \\
\hline Letno & $10,22^{*}$ & 4.39 & 2,33 & 6,64 & 4,47 & 1,48 \\
\hline
\end{tabular}

O meni so širili laži.

\begin{tabular}{lllllll}
\hline Tedensko & $-20,06^{*}$ & 9.33 & $-2,15$ & 6,48 & 10,46 & 0,62 \\
\hline Mesečno & $-17,77^{*}$ & 6.94 & $-2,56$ & 9,04 & 7,02 & 1,29 \\
\hline Letno & $-2,36$ & 3.97 & $-0,60$ & 7,86 & 4,37 & 1,80 \\
\hline Prisilili so me početi stvari, ki jih nisem želel. & & & & \\
\hline Tedensko & $-25,49$ & 19.09 & $-\mathrm{I}, 34$ & $-41,39^{*}$ & 14,89 & $-2,78$ \\
\hline Mesečno & $-12,33$ & 16.17 & $-0,76$ & $-30,8 \mathrm{I}^{*}$ & 14,40 & $-2,14$ \\
\hline Letno & 4,66 & 6.03 & 0,77 & $-18,49^{*}$ & 7,09 & $-2,6 \mathrm{I}$ \\
\hline \multicolumn{7}{c}{$\mathrm{R}^{2}=0,0 \mathrm{I}(0,0 \mathrm{I})$} \\
\hline
\end{tabular}

V osmem razredu izpostavljenost nasilju skoraj v nobeni posamezni postavki ni povezana z naklonjenostjo za učenje tako kemije kot matematike. Učenju so manj naklonjeni fantje, ki jim kdo redno kaj ukrade, in dekleta, ki jih drugi tedensko prisilijo, da počnejo nekaj, kar ne želijo, druge povezave pa niso značilne. 


\section{Razprava}

Regresijske analize povezave med učenčevo zaznano izpostavljenostjo nasilju na šoli in percepcijo spodbudnega šolskega okolja ter naklonjenostjo do učenja in dosežki je odkrila nove poglede na pomembnost šolske klime. Ugotovili smo, da se narava povezav med štirimi opazovanimi kazalci razlikuje med mlajšimi in starejšimi učenci ter med fanti in dekleti. Posamezni dejavniki, s katerimi je bila izmerjena zaznava varnega šolskega okolja, so različno povezani z dosežki fantov in deklet ter dosežkov mlajših in starejših učencev.

Med spoloma je opaziti nekaj razlik v napovednih dejavnikih. Četrtošolci so deležni več nasilja kot četrtošolke in občutijo tudi nižjo pripadnost šoli. Osmošolke čutijo večjo pripadnost šoli kot osmošolci. V naklonjenosti do učenja matematike in naravoslovja v četrtem razredu oziroma kemije v osmem razredu med spoloma ni razlik.

Če povzamemo, so regresijske analize pokazale statistično značilne povezanosti:

- med občutkom pripadnosti šoli in dosežki v obeh razredih in pri obeh spolih;

- med občutkom pripadnosti šoli in naklonjenostjo do učenja $\mathrm{v}$ obeh razredih in pri obeh spolih,

- med zaznano izpostavljenostjo nasilju ter dosežki iz matematike in naravoslovja v četrtem razredu,

- med zaznano izpostavljenostjo nasilju ter naklonjenostjo do učenja matematike in kemije v osmem razredu pri fantih,

- med zaznano izpostavljenostjo nasilju in naklonjenostjo do učenja kemije v osmem razredu pri dekletih.

Med četrtošolci, ki so v povprečju stari okoli to let, je manjša izpostavljenost nasilju povezana $\mathrm{z}$ višjimi matematičnimi in naravoslovnimi dosežki, kot je bilo pričakovano in potrjuje tudi druga raziskovalna literatura. Nasprotno se je občutek večje pripadnosti šoli izkazal za povezanega z nižjimi dosežki iz matematike in naravoslovja. Učenci, ki so potrdili, da se v šoli dobro počutijo, so hkrati dosegli nižje znanje oziroma učenci, ki so dosegli višje znanje, so se hkrati v šoli počutili slabše kot manj uspešni učenci, ne glede na lastno zaznavo izpostavljenosti nasilju. Rezultat se sklada z že ugotovljeno večjo kritičnostjo bolj uspešnih učencev osmega razreda v Sloveniji do izvedbe pouka in učiteljev, ko uspešnejši učenci ugotavljajo, da se učitelji bolj posvečajo njihovim manj uspešnim sošolcem (Japelj, 2017). Učiteljevo zavzetost do poučevanja ocenjenjujejo nižje kot manj uspešni učenci. Rezultat opravljene regresijske analize 
za obe starostni populaciji opozarja na pojav zgodnjega začetka nelagodja v šoli med uspešnimi učenci, že v četrtem razredu, in zahteva nadaljnjo pozornost.

Med osmošolci je z dosežki pozitivno povezan le občutek pripadnosti šoli, ne pa izpostavljenost nasilju. Občutek pripadnosti šoli in izpostavljenost nasilju skupaj sicer ne pojasnita velikega deleža variance med dosežki. Zaradi statistične značilnosti povezav pa je rezultat optimističen, saj kaže, da učenčeva zaznava izpostavljenosti nasilju in klime na šoli na splošni ravni v osmem razredu ni več neposredno povezana s pridobivanjem znanja.

Modeli povezanosti med dejavnikoma občutka pripadnosti šoli in naklonjenostjo do učenja, ki so bili izračunani ločeno po spolu, so pojasnili večji del variance $\mathrm{v}$ naklonjenosti do učenja kot variance $\mathrm{v}$ dosežkih. Večji delež variance kot pri dekletih so modeli pojasnili med dečki in fanti, skoraj četrtino. Velik delež pojasnjene variance je obetaven rezultat, ker za dva dejavnika potrjuje, da sta relativno močno povezana z naklonjenostjo do učenja ali, širše, $z$ učenčevo motivacijo. Dosedanje študije namreč niso uspele odkriti neposrednih razlogov za skrajno nizko naklonjenost do učenja med slovenskimi učenci, sploh ob njihovih nasprotujočih, relativno visokih dosežkih. Kaže, da se z naklonjenostjo do učenja povezuje šolska klima, ne pa dosežki. To bi lahko pojasnilo nizko motivacijo učencev, ki se v šoli ne počutijo varne, vendar to ne vpliva na višino doseženega znanja. Osnovne analize raziskave TIMSS so pokazale, da je še posebej $\mathrm{v}$ četrtem razredu povezanost med podporo domačega okolja in otrokovimi dosežki med slovenskimi učenci velika in bi lahko deloma pojasnila visoke dosežke učencev $\mathrm{z}$ visoko podporo doma, ki se v šoli ne počutijo varne. Tudi med učenci osmega razreda je občutek pripadnosti šoli povezan z naklonjenostjo do učenja matematike oziroma kemije pri obeh spolih.

Izpostavljenost nasilju kaže drugačno sliko. Pri dekletih je povezana le z naklonjenostjo do učenja kemije, pri fantih pa tudi z naklonjenostjo do učenja matematike, vendar vsakič negativno. To pove, da učenci, ki se čutijo manj izpostavljene nasilju, hkrati dosegajo nižje rezultate od učencev, ki se čutijo nasilju bolj izpostavljeni. Drugače, učenci, ki so bolj nakonjeni učenju, se čutijo nasilju bolj izpostavljene. Rezultat se sklada z že znanim dejstvom o pozornosti učiteljev pri pouku. Spomnimo, da učenci z višjimi dosežki ocenjujejo, da so njihovi učitelji pri pouku do njih manj pozorni, kot to ocenjujejo učenci z nižjimi dosežki. Izpostavljenosti nasilju torej ne smemo razumeti kot značilnosti učencev z nižjimi dosežki, pač pa je treba usmeriti pozornost $\mathrm{k}$ obravnavi nasilja tudi pri učencih, ki so zelo uspešni v šoli. 
Rezultati analiz na drugem koraku, ko smo opazovali posamezne elemente dejavnikov varnega in spodbudnega okolja, so izpostavili nekatere nove poglede na šolsko klimo. Med osnovnimi rezultati je dobrodošel predvsem visok delež otrok, ki potrjujejo, da se v svoji šoli veliko naučijo, med četrtošolci skoraj vsi, med osmošolci pa več kot $80 \%$. Visoki deleži učencev tudi poročajo, da v šoli nikoli ne doživijo nasilja.

Med vidiki spodbudnega šolskega okolja v četrtem razredu se z motivacijo do učenja povezujejo veselje do bivanja v šoli, občutek varnosti na šoli, ponos na šolo in ocena šolske učinkovitosti v poučevanju. V skladu s pričakovanji so vse povezave pozitivne. Veselje do bivanja $\mathrm{v}$ šoli je pozitivno povezano z naklonjenostjo do učenja, kar pomeni, da so učenci, ki so raje $\mathrm{v}$ šoli, bolj naklonjeni učenju matematike in naravoslovja kot učenci, ki so manj radi v šoli. Dečki z večjim občutkom varnosti, ki so bolj ponosni na šolo, se raje učijo. Pri deklicah varnost in ponos na šolo z naklonjenostjo učenju nista povezana. Učenci, ki se jim bolj zdi, da se na šoli veliko naučijo, so tudi bolj motivirani za učenje. Pri dečkih to celo najbolj poveča motivacijo za učenje med vsemi opazovanimi dejavniki. Rezultat odkriva nekatere možnosti vpliva sistema in odraslih na motivacijo učencev. Povratna informacija o znanju, ki učencem utrjuje zavest, da se veliko naučijo, se kaže kot pomemben spodbujevalec motivacije za učenje. Drugi najpomembnejši dejavnik pa je veselje do preživljanja časa v šoli. Oboje je mogoče doseči v okviru šolske avtonomije, če so učitelji in drugi odrasli na to dovolj pozorni. Varnost na šoli je za motivacijo pomembna, ima pa majhen učinek, podobno kot učenčev ponos na svojo šolo.

Povezave med elementi spodbudnega šolskega okolja in učenčevo naklonjenostjo do učenja se do osmega razreda spremenijo. Za naklonjenost do učenja ostaneta pomembna veselje do bivanja v šoli in ocena o učinkovitosti poučevanja na šoli. Občutek varnosti in ponos na šolo pa zamenjata odnos z učitelji in veselje do druženja z vrstniki. Med dekleti in fanti so $\mathrm{z}$ naklonjenostjo do učenja matematike in naravoslovja pozitivno povezani prvi trije, druženje z vrstniki pa rahlo odstopa od drugih. Napoved naklonjenosti do učenja je najbolj znižana v skupini učencev, ki niso radi v šoli, glede na tiste, ki so v šoli zelo radi, pri obeh spolih.

Občutek učencev, da se v svoji šoli veliko naučijo, napoveduje manj razlik v naklonjenosti do učenja med tistimi, ki bolj soglašajo, da se na šoli veliko naučijo, od tistih, ki manj soglašajo z izjavo. Povezanost med naklonjenostjo do učenja in učenčevo oceno, da so učitelji do njega pošteni, je močnejša pri fantih kot pri dekletih. Veselje do druženja s sošolkami in sošolci je negativno povezano z naklonjenostjo do učenja, bolj izrazito med dekleti kot med fanti. Učenci, ki gredo v šolo radi zato, da se srečajo s prijatelji, so manj zavzeti za učenje. Sporočilo napovednega modela za dvig 
motivacije za učenje je jasno: doseči, da bodo učenci radi v šoli in bodo dobili dobro povratno informacijo, da se v šoli veliko naučijo. Za fante je posebej pomembno, da so učitelji do njih pošteni. To je skladno z rezultati študije o ocenjevanju v osmem razredu (Japelj in Cankar, 2018), ki je pokazala dvoje: da so fantje pogosto ocenjeni nižje, kot je njihovo znanje, ter da ocenjevanje $\mathrm{v}$ naših šolah pogosto ne meri in ne prepozna zahtevnejšega znanja, ki ga imajo fantje. Veselje do druženja z vrstniki, ki je večje ob nižji motivaciji za učenje, je lahko izraz iskanja razlogov za hojo v šolo ob pomanjkanju veselja in uspeha $\mathrm{z}$ učenjem, posebej med dekleti.

Podrobnejši vpogled v izpostavljenost nasilju je v četrtem razredu razkril, da so z doseženim znanjem močneje povezane nekatere specifične oblike nasilega vedenja, čeprav je nasilja na splošno malo. Dosežki so izrazito nižji $v$ primeru, da je učenec izpostavljen rednim primerom kraje svojih predmetov. Dečki in deklice, ki jim redno tedensko kradejo, v naravoslovnem dosežku precej izrazito zaostajajo za vrstniki, ki jim nihče ne krade, dečki sicer še bolj kot deklice. Drugo nasilno dejanje, ki se povezuje z nižjim dosežkom, je širjenje neprijetnih informacij o učenkah, tudi če se dogaja le nekajkrat na leto, in o učencih, če se dogaja tedensko. Obe dejanji se od drugih nasilnih dogodkov, ki smo jih opazovali v kazalcu izpostavljenosti nasilju, razlikujeta po tem, da je povzročitelj anonimen in zlahka ostane nerazkrit. Med dečki ima pomemben vpliv na njihovo učenje še izključevanje iz igre ali iz sodelovanja $z$ drugimi, še posebej $k$ temu prispevajo dogodki, ki jih otrok zaznava, da se zgodijo le nekajkrat na leto. Predvidevamo, da so to tisti, ki so med bolj problematičnimi in pustijo na otroku močan vtis. Rezultati sporočajo o povezanosti med znanjem in nasiljem, vendar kažejo tudi na specifično pomanjkanje določenih informacij, da bi lahko takoj razvili strategije in protokole ukrepanja. Ne vemo, kaj so razlogi, da je posamezni učenec izločen iz igre ali sodelovanja, prav tako ne vemo, kaj so razlogi za širjenje neprijetnih informacij o posamezniku. Čeprav je oboje nesprejemljivo, pa bi potrebovali dodatne natančnejše opise situacij, da bi lahko razvili splošno preventivo. Potrebno bi bilo pozorno spremljanje pojavljanja takšne oblike dogodkov še $s$ strani odgovornih odraslih. Kljub skopim trenutnim informacijam analiza šolam sporoča, da naj bodo še posebej do dogodkov, ki niso demonstracija fizičnega nasilja, pozornejše in naj jih razumejo dovolj resno v povezavi z zagotavljanjem enake pravice do znanja za vse učence. Povezanost nasilnih dogodkov, ki niso fizično nasilje, je z dosežki učencev namreč presenetljivo močna.

$\mathrm{V}$ osmem razredu je povezanost motivacije za učenje $\mathrm{z}$ zaznavo nasilja manjša kot v četrtem razredu. Izrazito se loči po spolu. $\mathrm{Z}$ motivacijo deklet za učenje je močno povezana incidenca širjenja laži o njih. Dekleta, 
ki poročajo, da se jim to dogaja tedensko, demonstrirajo velik zaostanek v znanju matematike. Med fanti je bistveno nižje znanje matematike povezano s pogostim siljenjem v neželene aktivnosti. Učenci, ki jih drugi silijo, da tedensko počnejo reči, ki jih ne želijo, izkazujejo še dvakrat večji zaostanek v znanju matematike za tistimi, ki se jim to ne dogaja nikoli, kot dekleta, o katerih se širijo laži. Čeprav je nasilje v celotnem slovenskem šolskem prostoru v tej starosti precej redko, pa tako izrazita povezanost $\mathrm{z}$ dosežki zahteva takojšnjo pozornost in razvoj strategij za prepoznavanje opisanih dejanj. Podobno kot pri četrtošolcih širjenje laži in siljenje v določene aktivnosti družita dve temeljni karakteristiki: ne sodita med fizično nasilje ter imata pogosto anonimnega krivca. Posledično zlahka ostaneta skrita odraslim na šoli, nasilneži niso kaznovani, žrtve pa ne prepoznane. Oboje tudi povečuje osebno zadrego med učenci in je lahko povezano s skritim nadaljnjim izsiljevanjem, zato ne moremo pričakovati, da bi dejanja učenci prijavljali sami. Neposredno sporočilo odraslim in šolam je, da je nujno takoj povečati pozornost do nefizičnega nasilja, hkrati pa sistematično raziskati povode za ta dejanja, da bi lahko okrepili preventivno vzgojo in učencem omogočili pravično obravnavo vseh nadlegovanj. Izpostavljenost nadlegovanjem, ki niso fizično nasilje, je tudi med osmošolci močno povezana z doseganjem šolskega znanja.

Rezultati študije so ponekod tehnično zahtevni zaradi nujne natančnosti pri opazovanju redkih pojavov in občutljivih povezav. Glavna sporočila šolski politiki in strokovnjakom pa so jasna. Učenčeva zaznava spodbudnega šolskega okolja in izpostavljenosti nasilju na šoli sta relativno močno povezani tako $\mathrm{z}$ motivacijo za učenje kot $\mathrm{z}$ doseženim znanjem. Večja naklonjenost do učenja je verjetno najbolj povezana $z$ dejavniki šolskega okolja, kjer prevladuje učenčev občutek, da je rad v šoli in da se na šoli počuti varno. Višje znanje je verjetno najbolj povezano z dejavniki izpostavljenosti nasilnim dogodkom anonimnih povzročiteljev, ki niso fizično nasilje. Večino najbolj zaskrbljujočih dogodkov bi bilo mogoče preprečiti ali ustrezno obravnavati v okviru obstoječega delovanja šole, če bi pravladalo prepričanje, da tudi omenjeni dogodki zahtevajo vso resnost obravnave in reševanja. Potrebna sta večja razgledanost vpletenih odraslih o pomembnosti vpliva specifičnega dogajanja na šoli na otrokovo izobraževanje ter večje razumevanje določenih dogodkov kot resnih ovir za učenje. Za odrasli svet so širjenje laži, male tatvine in izločanje iz skupnih aktivnosti pogosto zanemarljive težave, $\mathrm{v}$ šolskem prostoru pa se izkazuje, da imajo prav ti dogodki dolgoročni vpliv na šolsko uspešnost otrok. Nenazadnje pa analiza sporoča še, da je za motivacijo za učenje pomembno, da so učenci ne samo radi pri urah predmeta, pač pa v šoli nasploh. Šola bi torej morala postati prostor, kjer bi otroci radi preživljali svoj čas. 


\section{Literatura}

Bowen, N.K., in Bowen, G.L. (1999) Effects of crime and violence in neighborhoods and schools on the school behavior and performance of adolescents, Journal of Adolescent Research I4(3), str. 319-342.

Chen, X., Rubin, K. H., in Li, D. (1997) Relation between academic achievement and social adjustment: Evidence from Chinese children, Developmental Psychology 33(3), str. 518-525.

Henrich, C. C., Schwab-Stone, M., Fanti K., Jones, S., M., in Ruchkin, V. (2004) The association of community violence exposure with middle-school achievement: A prospective study, Journal of Applied Developmental Psychology 25(3), str. 327-348. https://doi.org/10,1016/j. appdev.2004.04.004

IEA (2017) TIMSS SPSS Data. TIMSS \& PIRLS International Study Center, Lynch School of Education, Boston College.

Japelj Pavešić B. (2017) Kdo ima veselje z matematiko in naravoslovjem v šoli, Šolsko polje XXVIII (s-6), str. 55-86.

Japelj Pavešić B., in Cankar G. (2018) Linking Mathematics TIMSS Achievement with National Examination Scores and School Marks: Unexpected Gender Differences in Slovenia, Orbis Scholae I2(2), str. 77-100,

Katschnig, K., in Hastedt, D. (2017) Too scared to learn? Understanding the importance of school safety for immigrant students (Policy Brief No. 15). Amsterdam, The Netherlands: IEA.

Košir, K., Klasinc, L., Špes, T., Pivec, T., Cankar, G., in Horvat, M. (2019) Predictors of self-reported and peer-reported victimization and bullying behavior in early adolescents: the role of school, classroom, and individual factors. Eur J Psychol Educ. https://doi.org/10.1007/ S10212-019-00430-y

Martin, M. O., Mullis, I. V. S, Foy, P., in Hooper, M. (2016) TIMSS 2015 International Results in Science. Boston College, TIMSS \& PIRLS International Study Center.

Martin, M. O., Mullis I. V. S., in Hooper M. (ur.) (2016) Methods and Procedures in TIMSS 20I5. TIMSS \& PIRLS International Study Center, Boston College.

Milam, A. J., Furr-Holden, C. D., M., in Leaf, P., J. (200I) Perceived School and Neighborhood Safety, Neighborhood Violence and Academic Achievement in Urban School Children, Urban Rev 42(5), str. 458467. Doi 10,1007/si1256-010-0165-7 
Mullis, I. V.S in Martin, M. O. (ur.) (2013) TIMSS 2015 Assessment Frameworks. Boston College, TIMSS \& PIRLS International Study Center.

Mullis, I. V. S, Martin, M. O., Foy, P., in Hooper, M. (2016) TIMSS 2015 International Results in Mathematics. Boston College, TIMSS \& PIRLS International Study Center.

Perše, T. V., Kozina, A., in Leban, T. R. (2008) Negative school factors and their influence on math and science achievement in TIMSS 2003 , Educational Studies 37(3), str. 265-276.

Prusinski, E., Hastedt, D., in Dohr, S. (2018, November) Academic achievement and feelings of safety: A closer look at gender and grade level differences. IEA Compass: Briefs in Education No. 5. Amsterdam, The Netherlands: IEA.

Rutkowski, D., in Rutkowski, L. (2018) How systematic is international bullying and what relationship does it have with mathematics achievement in the 4th grade? IE A Compass: Briefs in Education No. I. Amsterdam, The Netherlands: IEA.

Shumow, L., in Lomax, G. (200I) Predicting perceptions of school safety, The School Community Journal II(2), str. 93-II2. 